\title{
Protein composition of rhapidosomes isolated from Aquaspirillum itersonii
}

\author{
Mehran Pazirandeh* and James R. Campbell \\ Center for Biomolecular Science and Engineering, Naval Research Laboratory, Washington, DC 20375, USA
}

(Received 17 August 1992; revised 27 October 1992; accepted 30 November 1992)

\begin{abstract}
Rhapidosomes are tubular microstructures composed of proteins that are found in a variety of bacteria and algae. These structures, which are resistant to disruption by many denaturing agents, have potential application as a biomaterial and may serve as a new model for the study of self assembly. When rhapidosomes were purified and analysed by SDS-PAGE the presence of three proteins with molecular masses of 53, 29 and $18 \mathrm{kDa}$ was revealed. However, lysozyme treatment of the rhapidosome preparations containing the three proteins resulted in the selective release of the $18 \mathrm{kDa}$ protein from the rhapidosome complex. N-Terminal sequence analysis and amino acid composition analysis were performed on all three proteins. The amino acid composition of the $18 \mathrm{kDa}$ protein closely matched the amino acid composition of protein $\mathrm{H}$ (a peptidoglycan-associated protein from Pseudomonas aeruginosa). These results suggest that the $18 \mathrm{kDa}$ protein may be a contaminating peptidoglycan-associated protein and not part of the rhapidosome structure. Western blot analysis using antisera raised against rhapidosomes revealed that the $53 \mathrm{kDa}$ component protein does not react with the antisera. We speculate that the $53 \mathrm{kDa}$ protein may form the inner core of the rhapidosomes, whilst the $29 \mathrm{kDa}$ protein forms the outer sheath of these structures.
\end{abstract}

\section{Introduction}

The self-assembly of protein monomers into higher order, tubular structures such as microtubules, flagella and pili occurs widely in nature. One type of tubular structure, called a rhapidosome, has been described in bacteria and algae (Correl \& Lewin, 1964; Chang \& Allen, 1974). Rhapidosomes contain a sheath that measures approximately $25 \mathrm{~nm}$ in diameter with a variable length and an inner core measuring approximately $8 \mathrm{~nm}$ in diameter. Although rhapidosomes are composed of protein subunits, once assembled they exhibit remarkable stability to a variety of extreme conditions such as treatment with acid, base, urea, guanidinium hydrochloride, and a range of organic solvents (Delk \& Dekker, 1972). Rhapidosomes have been described in several bacteria including Saprospira grandis and Aquaspirillum itersonii but remain poorly characterized, and their origin and function, as well as the mechanism of self-assembly, are currently unknown. These structures have been compared to microtubules of eukaryotes and phage particles. Evers \& Murray (1980) compared rhapidosomes and phage tail particles from

* Author for correspondence. Tel. (202) 4048438 ; fax (202) 767 1295.
A. itersonii but found them to be composed of distinct protein components and not related.

Besides being of interest as a new model for studying protein self-assembly, rhapidosomes may have potential use as a novel biomaterial. We recently reported a procedure for the metallization of these structures that may render them magnetic and electrically conductive (Pazirandeh et al., 1992). To gain insight into the function and mechanism of self-assembly of these structures we have begun a detailed study of rhapidosomes. Here we report our initial characterization of rhapidosomes from $A$. itersonii.

\section{Methods}

Materials. A. itersonii was obtained from the American Type Culture Collection (ATCC, Rockville, MD, USA). Precast polyacrylamide gels (4-20\%) were from Novex. Molecular mass markers were obtained from Bio-Rad. All other chemicals were from Sigma and were of reagent grade or better.

Bacterial growth and purification of rhapidosomes. Bacterial cultures were grown in peptone succinate-salt broth (Hylemon et al., 1973) for $72 \mathrm{~h}$ and then harvested by centrifugation at $6000 \mathrm{~g}$. The pellet was washed once in $100 \mathrm{ml}$ of $0.1 \mathrm{M}-\mathrm{Tris} / \mathrm{HCl} \mathrm{pH} 7.5$ and centrifuged again. The rhapidosomes were purified using two protocols. Protocol 1, a modification of the method of Evers \& Murray (1980), has been described previously (Pazirandeh et al., 1992). Protocol 2, described 
below, differs from protocol 1 in that the bacteria were treated with lysozyme to hydrolyse the peptidoglycan layer. Washed bacterial cells were resuspended in $100 \mathrm{ml}$ of $0.1 \mathrm{M}$-Tris $/ \mathrm{HCl}, \mathrm{pH} 7.5,0.005 \mathrm{M}$-EDTA and lysozyme was added to a final concentration of $0.2 \mathrm{mg} \mathrm{ml}^{-1}$. This suspension was kept on ice for $30 \mathrm{~min}$ and subsequently adjusted to $20 \mathrm{mM}^{-\mathrm{MgCl}_{2}}$. DNAase $(2 \mathrm{mg}$ ) was added and this suspension was gently stirred for $30 \mathrm{~min}$. SDS was added to a final concentration of $1 \%$ $(\mathrm{w} / \mathrm{v})$ and the sample was heated at $40^{\circ} \mathrm{C}$ for $1 \mathrm{~h}$. The SDS-treated sample was then centrifuged at $55000 \mathrm{~g}$ for $90 \mathrm{~min}$ and the supernate was discarded. The pellet was resuspended in $20 \mathrm{ml} 0.05 \mathrm{M}-\mathrm{Tris} / \mathrm{HCl}$, $\mathrm{pH} 7.5$, and centrifuged again as above. The pellet was resuspended as above and centrifuged at $15000 \mathrm{~g}$ for $20 \mathrm{~min}$. The supernate was collected and recentrifuged at $55000 \mathrm{~g}$ for $90 \mathrm{~min}$. The resulting pellet was resuspended in $0.5 \mathrm{ml} 0.05 \mathrm{M}-\mathrm{Tris} / \mathrm{HCl}, \mathrm{pH} 7.5$ and loaded onto a sucrose step gradient $(30-50 \%, \mathrm{w} / \mathrm{w})$. The gradient was centrifuged at $100000 \mathrm{~g}$ for $2 \mathrm{~h}$ and $0.5 \mathrm{ml}$ fractions were collected and analysed by SDS-PAGE. The fractions rich in rhapidosomes were pooled and dialysed in $0.05 \mathrm{M}$-Tris $/ \mathrm{HCl}, \mathrm{pH} 7.5$ for $8 \mathrm{~h}$ with one change of buffer.

SDS-PAGE and Western blotting. SDS-PAGE was performed essentially as described by Laemmli (1970). Purified rhapidosome samples were dissolved in solubilization buffer containing $50 \mathrm{~mm}-$ Tris $/ \mathrm{HCl}, \mathrm{pH} 7.5,3 \%$ (w/v) SDS, $1.7 \mathrm{M}-2$-mercaptoethanol and $20 \%$ ( $\mathrm{w} / \mathrm{v}$ ) glycerol, and boiled for $2-5 \mathrm{~min}$. Samples were then loaded on precast $4-20 \%(\mathrm{w} / \mathrm{v})$ gels and electrophoresed at $30 \mathrm{~mA}$ (constant current). Following electrophoresis, samples were stained with $0.1 \%$ Commassie blue in $50 \%(\mathrm{v} / \mathrm{v})$ methanol for several hours. The gels were destained with several changes in $50 \%$ methanol, $10 \%(\mathrm{v} / \mathrm{v})$ acetic acid. Western blotting was performed according to Towbin et al. (1979). Antisera was raised in rabbits using rhapidosomes prepared by protocol 1 as a source of antigen. Approximately $200 \mu \mathrm{g}$ rhapidosomes in a volume of $50 \mu \mathrm{l}$ was mixed with an equal volume of adjuvant (Hunter's Titer Max) and injected into the rabbit subcutaneously. At day 41 the rabbit was bled by arterial puncture and the serum recovered.

$N$-Terminal sequence and amino acid composition analysis. Rhapidosomes were subjected to SDS-PAGE and the proteins were transferred from the gel to polyvinylidene difluoride membranes according to Matsudaira (1987), and stained and destained as described above. The individual protein bands were excised from the membrane and were submitted to the Baylor College of Medicine Amino Acid Sequencing Facility for $\mathrm{N}$-terminal amino acid analysis and amino acid composition analysis.

Transmission electron microscopy. Five microlitres of the rhapidosome preparation was placed onto a Formvar-coated electron microscope grid for one min. Excess sample was removed with filter paper and the grid was stained with a $1 \%(\mathrm{w} / \mathrm{v})$ solution of uranyl acetate for $1 \mathrm{~min}$. Samples were viewed on a Zeiss model EM 10CR transmission electron microscope.

\section{Results and Discussion}

\section{Isolation and SDS-PAGE analysis of rhapidosomes}

During our initial work, rhapidosomes were isolated using a modification of the method of Evers \& Murray (1980) (protocol 1). This method involves the isolation of rhapidosomes from a fraction rich in murein sacculi. Whereas Evers \& Murray used sonication to release rhapidosomes from the murein sacculi, we used the detergent Sarkosyl to avoid extensive breakage of rhapidosomes that may occur during sonication.

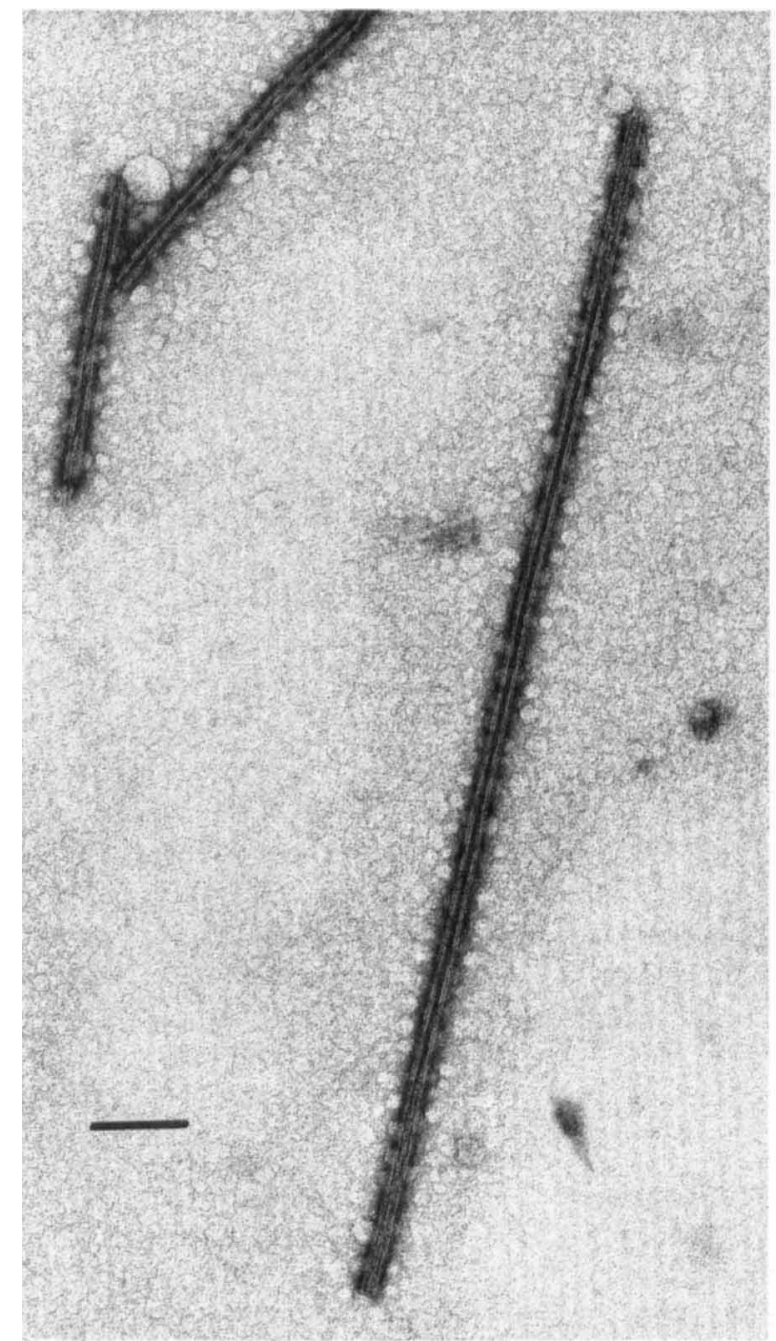

Fig. 1. Transmission electron microscopy of rhapidosomes. Rhapidosome preparation stained with $1 \%$ uranyl acetate. Bar, $100 \mathrm{~nm}$.

Electron micrographs of these preparations show rhapidosome sheaths with a diameter of $17 \mathrm{~nm}$ and variable lengths ranging up to $1300 \mathrm{~nm}$ (Fig. 1). These preparations, when analysed by SDS-PAGE, reveal the presence of three proteins with molecular masses 53, 29 and $18 \mathrm{kDa}$ (Fig. 2, lane 1). These are the same proteins that were reported as 55,29 and $16 \mathrm{kDa}$ proteins, respectively, in our previous publication (Pazirandeh et al. 1992). The omission of the sulphydryl reagent 2mercaptoethanol had no effect on the migration of these proteins (Fig. 2, lane 2), indicating these proteins are not held together by sulphydryl groups. However, with the exception of the $18 \mathrm{kDa}$ protein the rhapidosome component proteins appear to be in a stable complex and not disrupted unless boiled in solubilization buffer prior to SDS-PAGE (Fig. 2, lanes 3 and 4). 


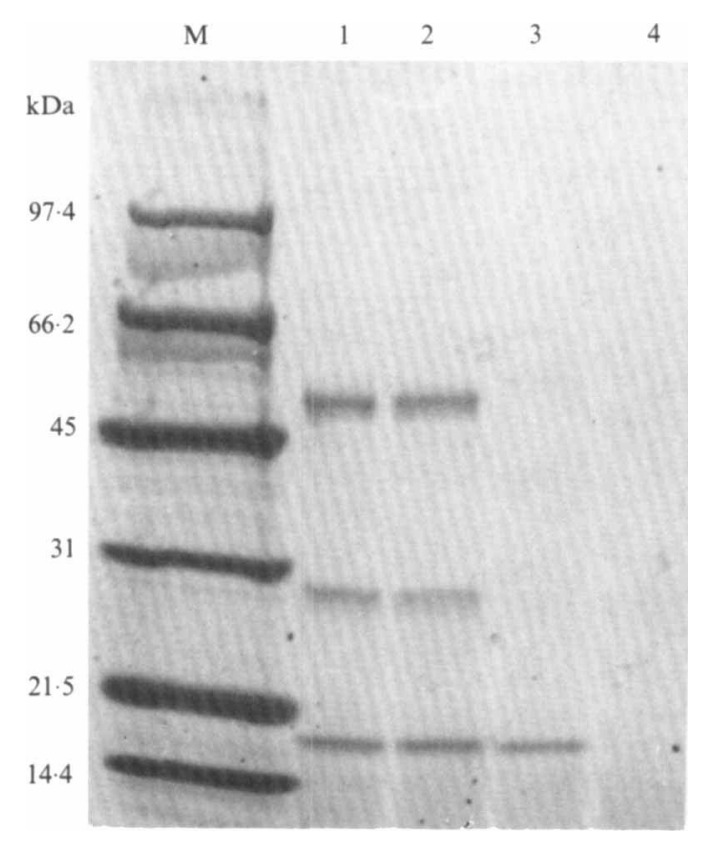

Fig. 2. SDS-PAGE analysis of rhapidosomes. Rhapidosomes purified using protocol 1 were added to an equal volume of solubilization buffer and treated as follows prior to SDS-PAGE analysis: lanes 1, boiled for 2 min; 2, boiled in solubilization buffer lacking 2-mercaptoethanol for $2 \mathrm{~min} ; 3$, heated to $60^{\circ} \mathrm{C}$ for $5 \mathrm{~min} ; 4$, held at $25^{\circ} \mathrm{C}$ for $5 \mathrm{~min}$. $\mathrm{M}$, molecular mass markers.

We had observed that when viewing rhapidosome preparations by the electron microscope, some fields were contaminated with what appeared to be cellular debris (membrane and/or cell wall components). In order to minimize this problem, rhapidosomes were subjected to an alternative purification protocol that involved treatment of the bacteria with lysozyme to hydrolyse the peptidoglycan layer, followed by further purification by sucrose gradient centrifugation (see protocol 2 in Methods). When these preparations were analysed by SDS-PAGE, it was observed that the rhapidosomes contained only the 53 and $29 \mathrm{kDa}$ proteins and lacked the $18 \mathrm{kDa}$ protein (Fig. 3). We reasoned, therefore, that the low molecular mass protein may be a contaminating cell-wall-associated protein and not part of the rhapidosomes.

To further define the origin of the $18 \mathrm{kDa}$ protein and determine whether treatment with lysozyme causes the solubilization of any or all of the rhapidosome component proteins, partially purified rhapidosomes were prepared by protocol 1 and subjected to lysozyme treatment. Following treatment with lysozyme, the samples were centrifuged at $55000 \mathrm{~g}$ for $90 \mathrm{~min}$ to pellet the rhapidosomes, and both the pellet and the soluble fraction were subjected to SDS-PAGE analysis. As shown in Fig. 4, without lysozyme treatment the rhapidosome component proteins $(53$ and $29 \mathrm{kDa}$ ), as

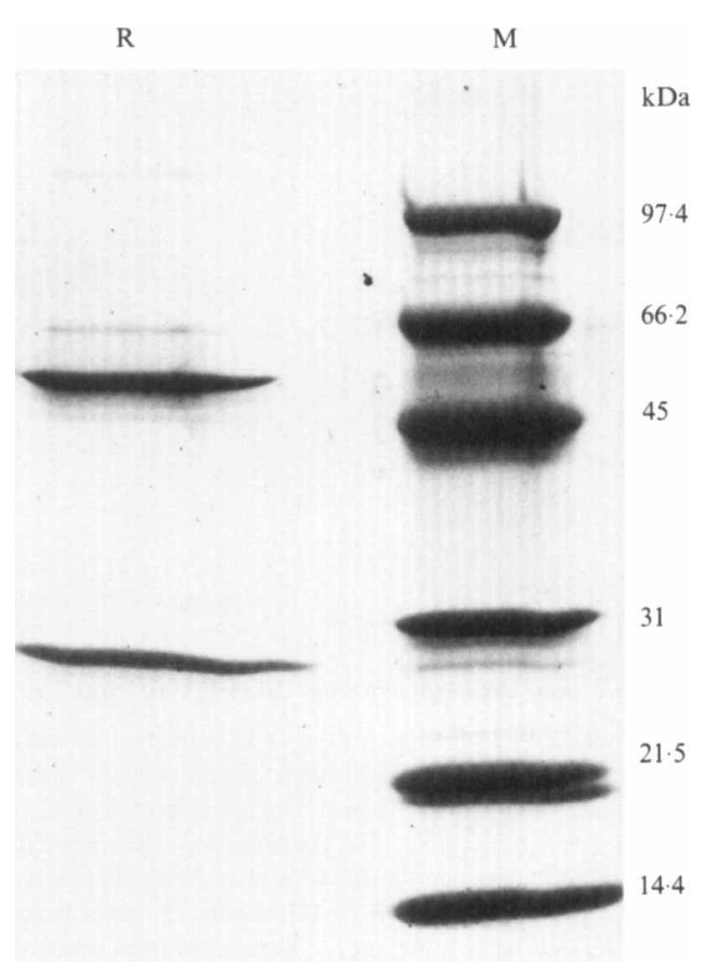

Fig. 3. SDS-PAGE analysis of rhapidosomes isolated by lysozyme treatment of bacteria (see Methods, protocol 2). Lanes: R, rhapidosomes; $\mathbf{M}$, molecular mass markers.

well as the $18 \mathrm{kDa}$ protein were pelleted at $55000 \mathrm{~g}$ (Fig. 4 , lane 1), whereas the supernate contained only a contaminating $42 \mathrm{kDa}$ protein (Fig. 4, lane 2). However after treatment with lysozyme some of the $18 \mathrm{kDa}$ protein was solubilized and appeared in the supernatant fraction (Fig. 4, lane 4, see arrow), whereas neither the $53 \mathrm{kDa}$ nor the $29 \mathrm{kDa}$ proteins were solubilized and remained in the pellet fraction (Fig. 4, lane 3). The lowest molecular mass band present in Fig. 4, lane 4 is lysozyme. Although it is possible that the $18 \mathrm{kDa}$ protein is part of the rhapidosome structure, its absence from preparations treated with lysozyme suggests that it may be a contaminating cell-wall- or peptidoglycan-associated protein. Several peptidoglycan-associated proteins have been isolated and characterized (Rosenbusch, 1974; Mizuno, 1987; Mizuno \& Kageyama, 1979). A common feature of these proteins that is also shared by the $18 \mathrm{kDa}$ protein described here is that they remain insoluble and associated with cell wall components in the presence of up to $2 \%$ SDS below $60^{\circ} \mathrm{C}$, but become solubilized above that temperature (see Fig. 2, lanes 3 and 4). We speculate that the presence of the $18 \mathrm{kDa}$ protein in rhapidosomes prepared by protocol 1 , as well as in rhapidosomes prepared by the Evers \& Murray (1980) method, and its absence in rhapidosomes prepared by protocol 2 is due to the fact that in protocol 2 the 


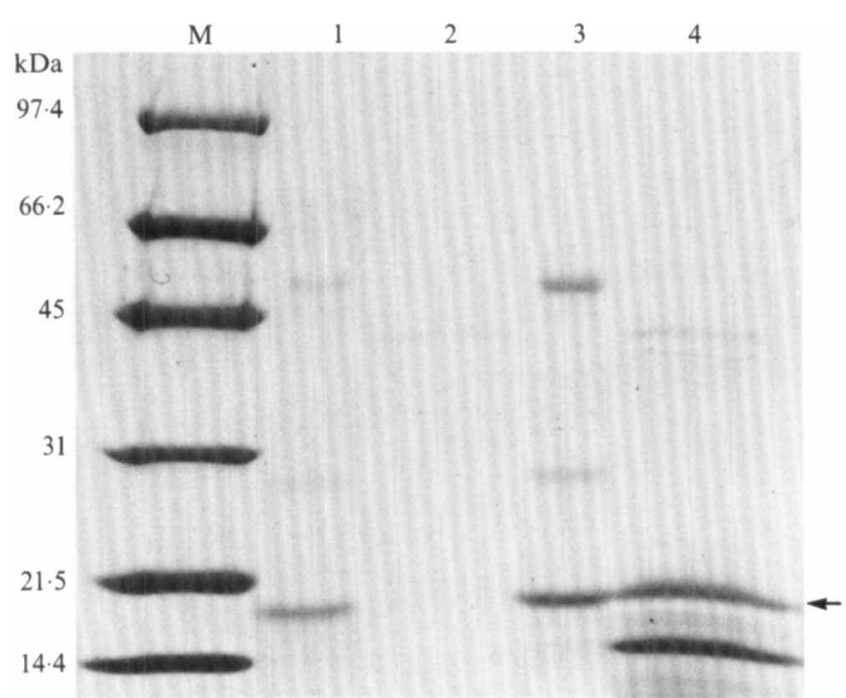

Fig. 4. Solubilization and release of the $18 \mathrm{kDa}$ protein by treatment of rhapidosomes with lysozyme. Purified rhapidosomes obtained by protocol 1 (containing all three proteins) were treated with lysozyme $\left(20 \mu \mathrm{g} \mathrm{ml}^{-1}\right)$ for $1 \mathrm{~h}$ at $4{ }^{\circ} \mathrm{C}$. The sample was then centrifuged at $55000 \mathrm{~g}$ for $90 \mathrm{~min}$ to pellet the rhapidosomes. The pellet, as well as the supernate were analysed by SDS-PAGE. Lanes: 1 , pellet from control sample not treated with lysozyme; 2 , supernate from control sample not treated with lysozyme; 3 , pellet from lysozyme-treated sample; 4, supernate from lysozyme-treated sample. $\mathbf{M}$, molecular mass markers. The arrow indicates the band in lane 4 representing the solubilized $18 \mathrm{kDa}$ protein in the supernate.

Table 1. $N$-terminal amino acid sequence of rhapidosome component proteins and $18 \mathrm{kDa}$ protein

\begin{tabular}{cc}
\hline $\begin{array}{c}\text { Protein } \\
(\mathrm{kDa})\end{array}$ & \multicolumn{1}{c}{ Sequence } \\
\hline 53 & P L I D K P E N A L L V V E K \\
29 & T A A F V D F Q H R L G K I \\
18 & A T G N T A P T T A G K R G P \\
\hline
\end{tabular}

bacteria are first treated with lysozyme to digest the peptidoglycan layer. The lysozyme treatment thus solubilizes and releases the $18 \mathrm{kDa}$ protein and therefore it does not appear in the rhapidosome fraction. However, neither the Sarkosyl treatment (protocol 1) nor sonication (Evers \& Murray) release the $18 \mathrm{kDa}$ protein from the peptidoglycan layer, and during the $55000 \mathrm{~g}$ centrifugation used to pellet rhapidosomes, some peptidoglycan material with its associated $18 \mathrm{kDa}$ protein is also pelleted and is present in these rhapidosome preparations.

\section{Amino acid sequence and composition analysis}

$\mathrm{N}$-Terminal amino acid sequence and amino acid composition analysis were performed for the rhapidosome component proteins as well as the $18 \mathrm{kDa}$
Table 2. Amino acid composition of the rhapidosome component proteins and $18 \mathrm{kDa}$ protein

The values for Trp, Asn and Gln were not determined.

\begin{tabular}{lrcc}
\hline \hline & \multicolumn{3}{c}{ Composition (mol \%) } \\
\cline { 2 - 4 } Amino acid & $53 \mathrm{kDa}$ & $29 \mathrm{kDa}$ & $18 \mathrm{kDa}$ \\
\hline Ala & 12.10 & 13.93 & $13 \cdot 71$ \\
Arg & 5.28 & 1.83 & $5 \cdot 14$ \\
Asp & 11.20 & 2.17 & $10 \cdot 22$ \\
Cys & 0.19 & $\mathrm{ND}$ & $\mathrm{ND}$ \\
Glu & 9.05 & 9.94 & 13.11 \\
Gly & 7.84 & 18.55 & 13.99 \\
His & 2.13 & 0.41 & 0.98 \\
Ile & 2.91 & 10.50 & 0.69 \\
Leu & 11.25 & 11.99 & 6.62 \\
Lys & 4.39 & 2.31 & 5.52 \\
Met & 0.17 & 0.33 & $\mathrm{ND}$ \\
Phe & 4.36 & 0.59 & 2.99 \\
Pro & 5.15 & 0.51 & 2.86 \\
Ser & 5.81 & 2.28 & 6.40 \\
Thr & 7.78 & 24.21 & 6.80 \\
Tyr & 3.80 & 0.24 & 1.83 \\
Val & 6.56 & 0.32 & 9.40 \\
\hline \hline
\end{tabular}

ND, Not detected.

protein. These data (Tables 1 and 2) reveal that these proteins are unique and not multimers of each other. Multimers of self-assembling proteins that are stable in SDS have been reported for other self-assembling structures such as pili (Parge et al. 1990) and the S-layer protein (Faraldo et al., 1991). A search of the NBRFPIR protein data bank for similar amino acid sequences did not reveal any homology to any of the three proteins.

The amino acid composition of the $53 \mathrm{kDa}$ protein did not reveal an abundance or lack of any particular amino acid. However, examination of the amino acid composition of the $29 \mathrm{kDa}$ protein revealed that threonine, glycine and alanine account for over $50 \%$ of the total amino acids of this protein. The significance of the abundance of these amino acids, particularly threonine is currently unknown. Further work aimed at cloning the genes encoding these proteins may reveal a new, and as yet unidentified, self-assembly motif present in this protein.

Examination of the amino acid composition of the $18 \mathrm{kDa}$ protein revealed a striking resemblance to the amino acid composition of one of the peptidoglycanassociated proteins (protein $\mathrm{H}$ isolated from Pseudomonas aeruginosa). Fig. 5 shows the comparison of the amino acid composition of the 53,29 and $18 \mathrm{kDa}$ proteins with protein $\mathrm{H}$. As shown in Fig. $5(a)$ the $18 \mathrm{kDa}$ protein and protein $\mathrm{H}$ compare very well in their amino acid composition whereas a comparison of the 29 and $53 \mathrm{kDa}$ proteins with protein $\mathrm{H}$ reveals significant differences in amino acid composition (Fig. $5 b$, and $c$, respectively). This observation further supports the 

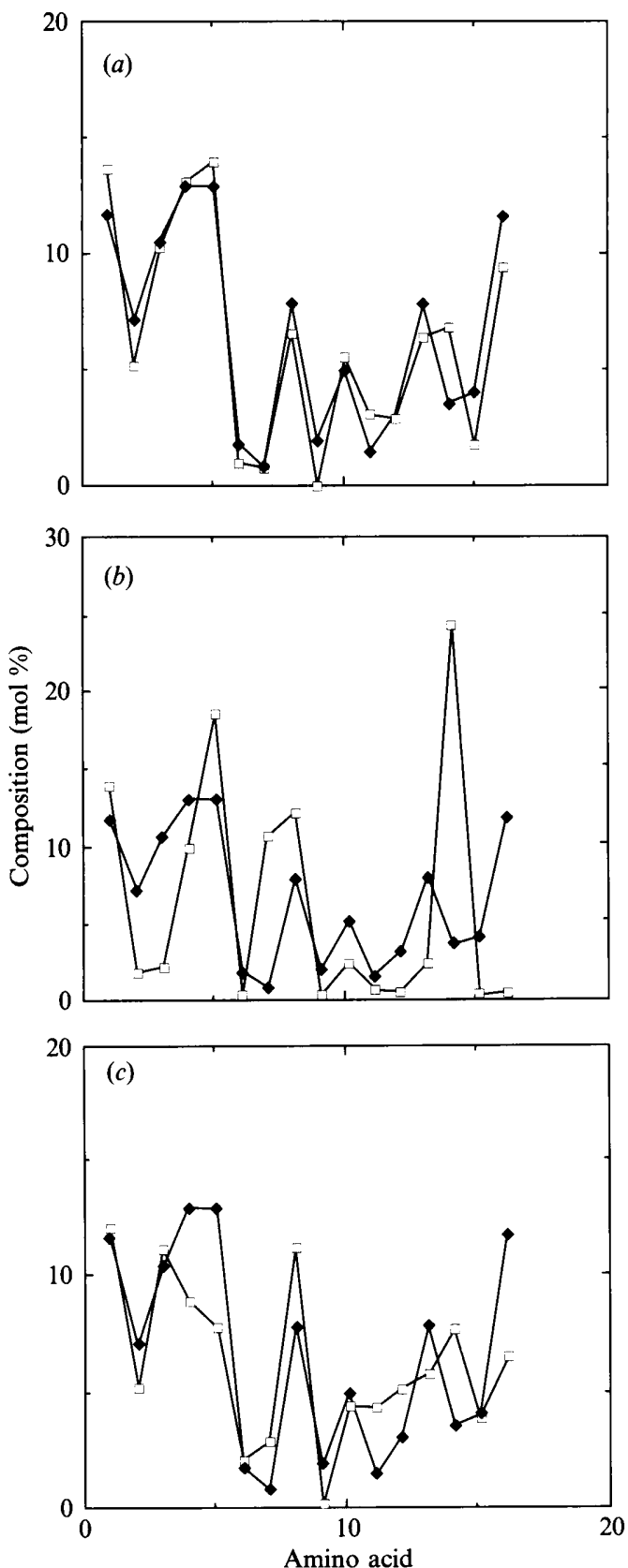

Fig. 5. Comparison of the amino acid composition of protein $\mathrm{H}$ from Pseudomonas aeruginosa $(\diamond)$ with $(a) 18 \mathrm{kDa}$ protein $(\square),(b) 29 \mathrm{kDa}$ protein $(\square)$ and (c) $53 \mathrm{kDa}$ protein $(\square)$. Amino acid designations are: 1, Ala; 2, Arg; 3, Asp; 4, Glu; 5, Gly; 6, His; 7, Ile; 8, Leu; 9, Lys; 10, Met; 11, Phe; 12, Pro; 13, Ser; 14, Thr; 15, Tyr; 16, Val.

hypothesis that the $18 \mathrm{kDa}$ protein may be a peptidoglycan-associated protein.

\section{Western blot analysis of rhapidosomes}

Antisera against rhapidosomes was raised in rabbits using rhapidosomes prepared by protocol 1 (containing all three proteins, see Fig. 2) as a source of antigen. The

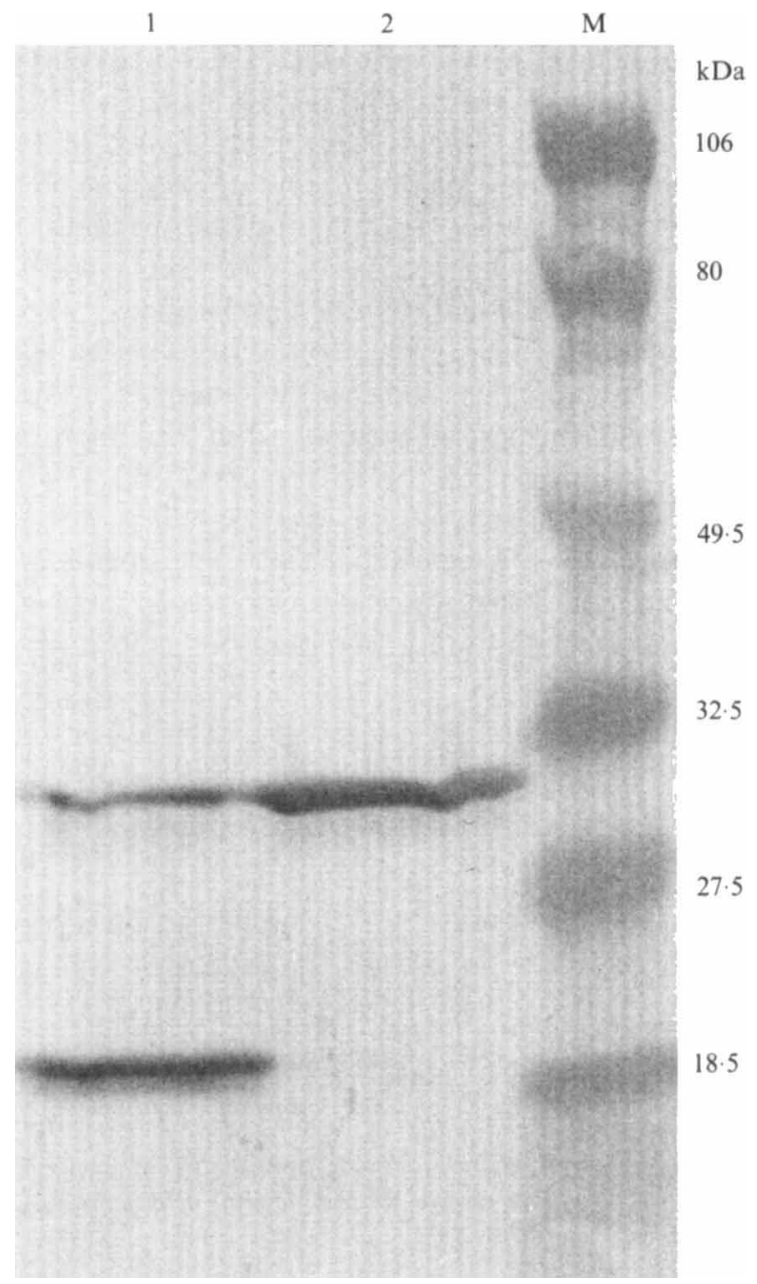

Fig. 6. Western blot analysis of rhapidosomes. Rhapidosomes isolated by either protocol 1 (lane 1) or protocol 2 (lane 2) were subjected to SDS-PAGE and analysed by Western blotting using antisera raised against native rhapidosomes. Lane $\mathbf{M}$, prestained molecular mass markers.

rhapidosome preparation used to produce the antisera, as well as the rhapidosome preparation that was purified using protocol 2 (with lysozyme) were subjected to SDSPAGE and Western blot analysis. Western blots revealed that the 18 and $29 \mathrm{kDa}$ proteins, but not the $53 \mathrm{kDa}$ protein, react with the antisera (Fig. 6). One possible explanation for the lack of reactivity of the $53 \mathrm{kDa}$ protein is that this protein may be located on the inside of intact rhapidosomes and is thus inaccessible to the immune system. Rhapidosomes from Saprospira grandis and Spirulina have been reported to contain an outer sheath and an inner core. The above results suggest that the $29 \mathrm{kDa}$ protein may form the sheath and the $53 \mathrm{kDa}$ protein may form the inner core of the molecule.

Although rhapidosomes were originally described almost 20 years ago, a comprehensive study regarding 
their function or the mechanism of assembly of these structures has yet to be completed. The potential use of rhapidosomes as a biomaterial derives from their ability to be metallized, their durability under extreme conditions, and their small size and anisotropic shape. Data are not currently available on the mechanism of self-assembly of rhapidosomes. However, with the availability of individual component proteins it should be possible to define the conditions under which rhapidosomes can be made to self-assemble. Whether rhapidosomes form spontaneously from their component proteins, or require additional factors (ATP, GTP) or proteins (rhapidosome-associated proteins) for selfassembly remains to be established. Experiments aimed at forming these structures in vitro from their component proteins are currently in progress in our laboratory.

This work was supported by contract N-0001492WX24180 from the Office of Naval Research. M.P. was supported by a postdoctoral fellowship from the Office of Naval Technology. The views presented in this paper are those of the authors and do not represent the opinion or policy of the U.S. Navy, Department of Defence, or the United States Government.

\section{References}

Chang, H. Y. \& Allen, M. M. (1974). The isolation of rhapidosomes from the blue-green alga, Spirulina. Journal of General Microbiology 18, 121-130.

Correll, D. L. \& Lewin, R. A. (1964). Rod shaped ribonucleoprotein particles from Saprospira. Canadian Journal of Microbiology 10, 63-74.
DeLK, A. S. \& DekKer, C. A. (1972). Characterization of rhapidosomes from Saprospira grandis. Journal of Molecular Biology 64, 287-295.

Evers, M. \& MuRRAY, R. (1980). The comparison of rhapidosomes and defective bacteriophage particles from Aquaspirillum itersonii. Canadian Journal of Microbiology 26, 1312-1319.

Faraldo, M. L. M., Pedro, M. A. \& Berenguer, J. (1991). Cloning and expression in Escherichia coli of the structural gene coding for the monomeric protein of the S layer of Thermus thermophilus HB8. Journal of Bacteriology 173, 5346-5351.

Hylemon, P. B., Wells, J. S., JR, KRieg, N. R. \& Jannasch, H. W. (1973). The genus Spirillum: a taxonomic study. International Journal of Systematic Bacteriology 23, 340-380.

LAEMMLI, U. K. (1970). Cleavage of structural proteins during the assembly of the head of bacteriophage T4. Nature, London 227,680-685.

Matsudaira, P. (1987). Sequence from picomole quantities of proteins electroblotted onto polyvinylidene difluoride membranes. Journal of Biological Chemistry 262, 10035-10038.

Mizuno, T. (1987). A novel peptidoglycan-associated lipoprotein found in the cell envelope of Pseudomonas aeruginosa and Escherichia coli. Journal of Biochemistry 86, 991-1000.

Mizuno, T. \& KageYAMA, M. (1979). Isolation and characterization of major outer membrane proteins of Pseudomonas aeruginosa strain PAO with special reference to peptidoglycan associated protein. Journal of Biochemistry 86, 979-989.

Parge, H. E., Bernstein, S. L., Deal, C. D., McRee, D. E., Christensen, D., Capozza, M. A., Kays, B. W., Fieser, T. M., Draper, D., So, M., Getzoff, E. D. \& Tainer, J. A. (1990). Biochemical purification and crystallographic characterization of the fiber-forming protein pilin from Neisseria gonorrhoeae. Journal of Biological Chemistry 265, 2278-2285.

Pazirandeh, M., Baral, S. \& Campbell, J. (1992). Metallized nanotubules derived from bacteria. Biomimetics 1, 39-48.

Rosenbusch, J. P. (1974). Characterization of the major envelope protein from Escherichia coli. Journal of Biological Chemistry 149, 8019-8029.

Towbin, H., Staehelin, T. \& Gordon, J. (1979). Electrophoretic transfer of proteins from polyacrylamide gels to nitrocellulose sheets: procedure and some applications. Proceedings of the National Academy of Sciences of the United States of America 74, 4350-4354. 